Mongolian Academy of Sciences
Mongolian Journal of Chemistry
Institute of Chemistry \& Chemical Technology

\title{
New isoquinoline alkaloid from Carduus crispus $\mathbf{L}$.
}

\author{
J.Tunsag', G. Davaakhuu'², D.Batsuren ${ }^{1}$ \\ ${ }^{1}$ Institute of Chemistry and Chemical Technology, Mongolian Academy of Sciences \\ ${ }^{2}$ School of Chemistry \& Chemical Engineering, National University of Mongolia, gda@num.edu.mn
}

\begin{abstract}
A new isoquinoline alkaloid, along with other known 4 bioactive compounds (1 isoquinoline alkaloid, 2 flavonoids, 1 coumarin), were isolated from the ethanol extract of aerial parts of Carduus crispus L. Crispine A N-oxide was newly isolated compound, two of them (quercetin and rutin) were compounds isolated for the first time from indicated plant. The structures of these compounds were elucidated and confirmed with spectroscopic methods e.g. ${ }^{1} \mathrm{H}-\mathrm{NMR},{ }^{13} \mathrm{C}-\mathrm{NMR}$, EI-MS, COSY, HSQC, HMBC, and by comparison with literature data.
\end{abstract}

Keywords: ethanol extract, chromatography, chloroform, crispine A N-oxide

\section{Introduction}

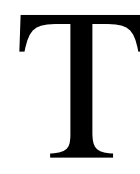

The genus Carduus (Compositae) comprises 95 species all over the world [1]. Two species (C.crispus $\mathrm{L}$. $\&$ C.nutans L.) are widely distributed in Mongolia [2]. Investigations of chemical constitutes showed that flavonoids, alkaloids and coumarins are the main components of this genus [1,3,4,5]. C.crispus is used in Mongolian traditional medicine for treatment of gland's cancer and as anaelgestics [6]. It has been shown that this plant has antioxidant and cell wall strengthening activity. It has been established the cytotoxic activity of the alcoholic extract of C.crispus. [3].

Isoquinoline alkaloids (crispine A-E, carcrisine A, B) and flavone glycoside were isolated from this plant collected in Inner Mongolia have been reported [1,3,5]. Herewith, we report about the isolation and structural elucidation of a new isoquinoline alkaloid; crispine A N-oxide. The ${ }^{1} \mathrm{H}$ and ${ }^{13} \mathrm{C}$
NMR spectral data of this compound are given for the first time.

\section{Experimental}

\section{Apparatus}

Melting point was determined on a Stuart SMP 10 apparatus. FABMS were measured on Bruker APEX II spectrometer. ${ }^{1} \mathrm{H}$ NMR and ${ }^{13} \mathrm{C}$ NMR (400 MHz) spectra (all in $\mathrm{CDCl}_{3}$ ) were recorded with a Bruker AM 400 , using TMS as internal standard. Silica gel 60 (Merck 0.063-0.200 mesh) was used for column chromatography. $\mathrm{Al}_{2} \mathrm{O}_{3}$ plates were used for TLC. Plates were visualized by spraying with Dragendorff's reagent.

\section{Plant material}

Aerial parts of C. crispus of its full flowering stage were collected in July 2003-2004, from Handgait place, near Ulaanbaatar city, Mongolia. A species was identified by Prof. Ch.Sanchir, Institute of Botany, Mongolian Academy of Sciences. Aerial parts of the 
samples were dried at room temperature and grinded.

\section{Extraction and isolation}

The plant material $(4.5 \mathrm{~kg})$ was weighed and extracted with $95 \%$ ethanol three times. The ethanol extract was concentrated by reducing pressure to dryness. After was added 5\% sulfuric acid to adjust $\mathrm{pH} 1$ and thoroughly shaked. The yielding alkaloidal acidic solution was filtered and treated with $\mathrm{NaHCO}_{3}$ to adjust pH 5. Basic solution was extracted with chloroform. Distillation of chloroform solution gave extract-A $25 \mathrm{~g}$. Adding to acidic solution $\mathrm{Na}_{2} \mathrm{CO}_{3}$ to adjust $\mathrm{pH} \quad 8$ and following extraction with chloroform after distillation yield extract-B, 23g. The extract-B was chromatographed over a silica gel with gradient $\mathrm{CHCl}_{3}-\mathrm{MeOH}$ $(100 \rightarrow 99: 1 \rightarrow 70: 30)$ to give 85 fractions. Fraction 35-39 were chromatographied on $\mathrm{Al}_{2} \mathrm{O}_{3}$ column eluted with $\mathrm{CHCl}_{3}-\mathrm{MeOH}$ (98:2) to yield compound CC-1 (64 mg).

\section{Results and Discussion}

\section{The structural identification}

Isoquinoline alkaloids were isolated from the ethanol extract of the aerial parts of C.crispus. Compound $\mathrm{CC}-1$, white needles, gave positive result in the Dragendorff test, $\mathrm{mp}$. $218-220^{\circ} \mathrm{C}$; molecular ion peak at $\mathrm{m} / \mathrm{z}$ 248,2645 $[\mathrm{M}]^{+}$(calcd for $\mathrm{C}_{14} \mathrm{H}_{19} \mathrm{NO}_{3}$ : 249.3081) was observed in the EI-MS spectrum. EIMS: $\mathrm{m} / \mathrm{z}=232,231,218,202$, 137, 113 and 81.

The ${ }^{1} \mathrm{H}$ NMR spectrum demonstrated signals for 19 protons in total. Two singlet at $\delta_{\mathrm{H}} 6.46$ $(1 \mathrm{H}, \mathrm{s})$ and $6.58(1 \mathrm{H}, \mathrm{s})$, indicating of the presence of $8,9,6 a, 10$ a tetra substituted phenyl ring, might be attributed to aromatic protons $(\mathrm{H}-7$ and $\mathrm{H}-10)$. The signals at $\delta_{\mathrm{H}}$ $3.77(3 \mathrm{H}, \mathrm{s})$ and $3.79(3 \mathrm{H}, \mathrm{s})$ were assigned to two methoxy groups and the other
11 signals at $\delta_{\mathrm{H}} 1.96-4.72$ were due to aliphatic protons.

The ${ }^{13} \mathrm{C}$ NMR indicated 14 signals, and DEPT experiment showed signals for two methoxy groups $\left(\delta_{\mathrm{C}} 56.18,56.02\right)$, five methylenes $\left(\delta_{\mathrm{C}}\right.$ $20.16,25.07,31.44,58.39$, 67.90), three methines $\left(\delta_{\mathrm{C}} 76.40,109.32,110.97\right)$ and four quaternary carbons $\left(\delta_{\mathrm{C}} 121.62,124.31\right.$, $148.52,148.72)$.

The chemical structure of compound CC-1 was identified by comparison of this ${ }^{1} \mathrm{H}$ and ${ }^{13} \mathrm{C}$ NMR spectral data with those of crispine A [3]. As shown in Table 1 carbon atoms C-3, $\mathrm{C}-5, \mathrm{C}-10 \mathrm{~b}$ linked to nitrogen atom of compound CC-1 have 10.19-14.84 ppm. downfield chemical shifts in comparison with molecule of crispine A (Tabl.1).

Table 1. ${ }^{1} \mathrm{H}$ and ${ }^{13} \mathrm{C}$ NMR (400MHz) and DEPT spectral data of Crispine A N-oxide and Crispine A $(\delta \mathrm{ppm}) *$

\begin{tabular}{|c|c|c|c|}
\hline \multirow{2}{*}{$\begin{array}{c}\text { Carbon } \\
\text { atom }\end{array}$} & \multicolumn{2}{|c|}{${ }^{13} \mathrm{C}$} & \multirow{2}{*}{ DEPT } \\
\hline & $\begin{array}{c}\text { Crispine A } \\
\text { N-oxide }\end{array}$ & $\begin{array}{c}\text { Crispine } \\
\text { A }\end{array}$ & \\
\hline C-1 & 31,44 & 30,49 & $\mathrm{CH}_{2}$ \\
\hline $\mathrm{C}-2$ & 20,16 & 22,17 & $\mathrm{CH}_{2}$ \\
\hline C-3 & $\begin{array}{c}67,90 \\
(+14,84)\end{array}$ & 53,06 & $\mathrm{CH}_{2}$ \\
\hline C-5 & $\begin{array}{c}58,39 \\
(+10,19)\end{array}$ & 48,20 & $\mathrm{CH}_{2}$ \\
\hline C-6 & 25,07 & 27,84 & $\mathrm{CH}_{2}$ \\
\hline $\mathrm{C}-7$ & 110,97 & 111,22 & $\mathrm{CH}$ \\
\hline C-8 & 148,72 & 147,27 & $\mathrm{C}$ \\
\hline C-9 & 148,52 & 147,17 & $\mathrm{C}$ \\
\hline $\mathrm{C}-10$ & 109,32 & 108,76 & $\mathrm{CH}$ \\
\hline C-6a & 121,62 & 126,03 & $\mathrm{C}$ \\
\hline C-10a & 124,31 & 130,63 & $\mathrm{C}$ \\
\hline C-10b & $\begin{array}{c}76,40 \\
(+13,51)\end{array}$ & 62,89 & $\mathrm{CH}$ \\
\hline $\mathrm{C}-\mathrm{OCH}_{3}$ & 56,18 & 55,81 & $\mathrm{CH}_{3}$ \\
\hline $\mathrm{C}-\mathrm{OCH}_{3}$ & 56,02 & 55,92 & $\mathrm{CH}_{3}$ \\
\hline
\end{tabular}

Researchers have established that, chemical shifts of carbon atoms adjacent to $\mathrm{N}$ atom undergo a downfield shift due to oxidation of nitrogen compounds to N-oxides [7]. This proves convertion of nitrogen atom in crispine A into N-oxide form. Because of absence of any information in literature about crispine $\mathrm{A}$ $\mathrm{N}$-oxide we assign that crispine A $\mathrm{N}$-oxide is new naturally occuring compound (Fig.1). 


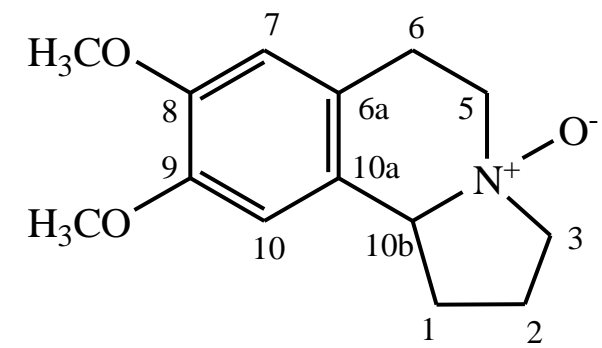

Figure 1. The structure of Crispine A N-oxide (8,9-dimethoxy-1,2,3,5,6,10b-hexahydro-pirrolisoquinoline $\mathrm{N}$-oxide)

Chemical method have used for provement of chemical structure of crispine A N-oxide. We have carried out reduction (deoxygenation) of crispine A $\mathrm{N}$-oxide and convert it to crispine A. The spectral data of newly synthesized product was similar to spectral data of crispine $\mathrm{A}$ and proves that crispine $\mathrm{A}$ is a precursor of crispine A N-oxide.

\section{Method of deoxygenation of crispine A}

Crispine A N-oxide was dissolved in 5ml 5\% sulfuric acid, added $\mathrm{Zn}$ powder, shaked permamently during 24 hours for providing chemical reaction. After end of reaction, the solution was filtered. Filtrate was alkalified by 5\% sodium hydroxide to adjust $\mathrm{pH} 8-9$ and was extracted by chloroform. Chloroform extract was concentrated in vacuo until dryness. Residue was chromatographed by using TLC with pure crispine A. Only one spot of crispine A have been detected in chromatogram, that prove that crispine A Noxide have been completely converted to crispine A by deoxygenation reaction (Fig.2). It is known to be that this method widely used for deoxygenation of $\mathrm{N}$-oxides [7].

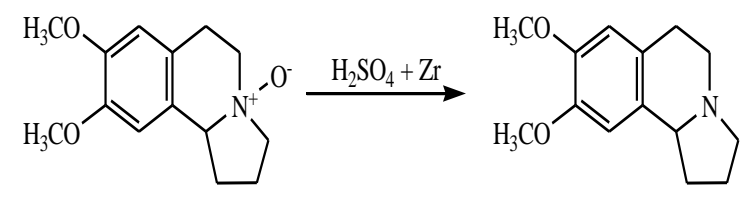

Figure 2. Deoxygenation of crispine A Noxide

\section{Conclusion}

New isoquinoline alkaloid has been isolated from the aerial parts of C.crispus L. It's structure was confirmed by chemical and spectral analysis and named as crispine A Noxide.

\section{References}

1. Wei-Dong Xie., Ping-Lin Li., Zhong-Jian Jia. A new flavone glycoside and other constituents from Carduus crispus. Pharmazie.: 2005. 60: 233-236

2. Ligaa U., Davaasuren B.. Ninjil N. Medicinal Plants of Mongolia Used in Western and Eastern Medicines. Munkhiin Useg Printing, Ulaanbaatar.: 2005. pp. 490-491. (in Mongolian)

3. Qingyig Zhang., Guangzhong Tu., Yuying Zhao. Novel bioactive isoquinoline alkaloids from Carduus crispus. Tetrahedron.: 2002. 58, 67956798

4. Terentjeva.S.V., Krasnov.E.A. Coumarins and flavonoids of aboveground part of Carduus crispus L. and C.nutans L. Sankt-Peterburg.: Rastitel.res. 2003. 39(1): pp55-64

5. Wei-Dong Xie., Zhong Jian Jia. Two new isoquinoline alkaloids from Carduus crispus. Chinese Chemical Letters. 2004. 15(9): pp 1057-1059

6. B.Boldsaikhan.,Ts.Oyuntsetseg. Dictionary of food and drug substances. 2000. pp.107 (in Mongolian)

7. Pelletier S.W. Alkaloids: Chemical and biological perspectives. 2001. Vol.15. pp.299-301 